THURSDAY, NOVEMBER I2, 1885

\section{THE INTERNATIONAL SANITARY CONFERENCE OF ROME, I88;}

THE first volume of the Proceedings of the International Sanitary Conference of Rome has been issued just at the time when the question of the reassembling of the Conference is a matter of diplomatic discussion. The Roman Conference of this year was brought together by the Italian Government because it was felt that, after the cholera experience of $\mathrm{J} 883$ in Egypt and of 1884 in Southern Europe, advance might be made in determining the bases of an International Code as to quarantine or other preventive measures. The previous Conference had been held at Vienna in I874, and the conclusions then arrived at had indicated substantial progress since the preceding meeting at Constantinople in I866. Under these circumstances nearly all civilised Governments responded to the appeal of Italy, and five delegates were deputed to represent this country. Two of these, Sir W. Guyer Hunter and Dr. Thorne Thorne, acted with the British Ambassador at Rome for Great Britain, and Sir Joseph Fayrer with Dr. Timothy Lewis went as representatives of our Indian Empire. Soon after the opening proceedings, a Technical Commission, consisting of the medical delegates, was formed, and it is essentially with the proceedings of that Commission that the volume referred to has to do.

With the ready assent of Dr. Koch, the Commission decided at the onset not to discuss scientific questions bearing upon etiology or otherwise, and the series of resolutions arrived at deal almost exclusively with the measures which are deemed necessary to prevent the spread of cholera in Europe. Perusal of the proceedings at once shows that the Powers bordering on the Mediterranean had one principal object in view. They were convinced that shipping passing from India viâ the Suez Canal constituted the great source of danger to ports on the basin of the Mediterranean; they knew that the sanitary state of the majority of those ports could not withstand the importation of infection; hence, cost what it might to other nations, they were determined to place restrictions upon shipping passing through the canal. It is true that the utter failure of quarantine measures had once more been abundantly shown during the 1884 epidemic, and for this reason the Commission decided to drop the word quarantine altogether; and they proposed, instead of the ten days' quarantine which had been sanctioned at Vienna, to require a detention of five days for the purposes of "observation." But, as was pointed out by the English delegates, this was quarantine pure and simple, for it involved the disembarkation of all on board vessels which might be regarded as infected by some internationally appointed officer, and the detention of men, women, and children in the filthy lazarets of the Red Sea shores for as many consecutive periods of five days as the officer in question might choose to dictate, so long as he could regard any one amongst the persons thus isolated as having suffered from symptoms which in his opinion resembled cholera. As regards European protection, it was also contended that such a measure was unnecessary in the case of British ships, and the Commission were twice challenged to give a single instance in which cholera had been brought into the continent of Europe by means of a British ship coming from India. And if it was unnecessary, it was contended that, provided British ships touched at no ports on their way home, they should be allowed the free passage of the Stez Canal as of an ordinary arm of the sea.

But quarantine restrictions were not only held to be unnecessary, they were also shown to be distinctly mischievous in so far as they led the inhabitants of threatened countries to rely on Government measures of that description instead of adopting measures of sanitation which constituted the true remedy against cholera spread. And here the experience of England was shown to be strikingly opposed to quarantinc. It is now some ten years since England, adopting one of the alternative measures sanctioned at Vienna, decided that since quarantine must always fail, the country would place its trust in an inspection of in coming vessels, together with the immediate isolation of the sick in hospital, and in securing such improvement in the sanitary state of the country as would tend to remove the conditions favourable to the diffusion of cholera if imported. And Dr. Thorne Thorne, whilst pointing out in detail that during that period of ten years our sanitary authorities had spent some $27,250,000 l$. in large public health works and that this had in truth been a remunerative expenditure by reason of the saving of life which had followed it, asked what country had shown a greater proof of the value it set on human life than England had, and contended that it would be an unfortunate day if we were to replace such a system by the imposition of a five days' quarantine. Indian statistics proving similar results were also brought forward by Sir Joseph Fayrer, and they must be regarded as unanswerable.

In short, the Engiish delegates contended that we must look, above all, to improved sanitation in order to get rid of the danger of cholera; that countries which are taught to rely on the false security of quarantine measures and sanitary cordons will not at the same time spend their money on sanitation; and that the very countries which had fitted themselves to resist cholera by making real and substantial progress as regards sanitary improvements, and had thus effected a saving in life from infectious diseases, were those which had determined to place little or no trust in measures of quarantine.

Compared with the resolutions of the Vienna Conference, the conclusions arrived at in Rome do in many respects admittedly afford evidence of considerable advance, but they are vitiated by the initial error of trusting to modified quarantine restrictions, instead of boldly facing the need for improved sanitation. As yet these conclusions are those of the Technical Commission only, and it remains to be seen whether, since the English delegates are opposed to their colleagues on a matter of such vital principle, any object will be gained by the re-assembling of the Plenary Conference, to discuss the recommendations made by the Commission.

VOL. XXXIII.-No. 837 